\title{
Measuring Housing Adequacy in Sao Paulo Metropolitan Region
}

\author{
Arthur Acolin ${ }^{*}$ and Richard K. Green ${ }^{\dagger}$
}

\begin{abstract}
Brazil has largely accomplished its urban transition but housing conditions for many residents of its urban centers remain such that they have large negative effects on individual and social welfare. This report develops a comprehensive measure of housing adequacy based on seven different deficiencies and estimates the number of households living in these conditions in Sao Paulo metropolitan region over the period 2007-2013 using PNAD data. These housing situations necessitate policy responses but the nature of these interventions differs and cannot be limited to programs to build new units for owner occupancy using public subsidies. Our main departure from existing measures of housing needs is to estimate housing costs for owners using the owner equivalent rent approach and develop a measure of affordability that combines housing and transportation costs as a share of income. This first attempt to develop a comprehensive affordability indicator is limited by data constraints but indicates that the rise in the number of households spending or who would be spending more than 45 percent of their income on housing and transportation costs combined has been increasing rapidly over the period studied.
\end{abstract}

Acknowledgements: The authors are extremely grateful for the expertise and support provided by Diana Motta, Director, Emplasa and her colleagues at Emplasa, particularly Vladimir Maciel and Fernanda Costa. We have also greatly benefited of the knowledge of the Brazilian housing system and of the advice given by Emilio Haddad, João Meyer and Claudia Eloy, and of meetings at IPEA and IBGE with Cimar Azeredo, Bernardo Furtado, Vicente Neto, and Cleandro Krause. Arthur Acolin thanks the Lusk Real Estate Center for its financial support and the Department of Tecnologia da Arquitetura, Faculdade de Arquitetura e Urbanismo, Universidade de São Paulo for providing him space to pursue this project. All errors remain our own.

\footnotetext{
*Arthur Acolin, Ph.D. Student, University of Southern California, acocapid@usc.edu, 2152060207

+ Richard K. Green, Lusk Chair in Real Estate, University of Southern California, richarkg@price.usc.edu, 213-7404093
} 


\section{Executive Summary}

Brazil's urban population grew from 18.8 million in 1950 to 161 million in 2010. At the same time, the average household size declined from above 5 to 3.3 (IBGE 2014). As a result, the need for new urban housing increased by over 45 million units over that 60 period, requiring the construction of 750,000 units a year, not accounting for attrition of the existing stock. While construction data from Brazil are not available for the entire period, we do know that not all households are currently housed satisfactorily. This indicates that the country was unable to produce the 750,000 or more housing units a year that it needed. So despite a considerable slowdown in the population growth rate over the last decades, a large number of urban households continue to live in substandard housing conditions.

Building on existing measures of housing needs, this report develops a more comprehensive measure of housing deficiencies, defined as 1) households who live in precarious units: units not designed to be residences, built with non-durable materials or that lack access to water or sanitation, 2) households who live in units that are not connected to basic infrastructures (sewer, water, electricity, trash collection), 3) households who live in units that lack legal infrastructure, such as land title and access to property registry, 4) overcrowded households, defined as those with more than three persons per bedroom, 5) households with cohabitating families whose member express the desire to form their own households, 6) households living in tenements (comodos) and 7) households who face housing cost burdens, defined as spending more than 45 percent of income on housing and transportation expenditures combined.

We use PNAD data to implement this definition of housing deficiencies for the Sao Paulo Metropolitan Region (RMSP) between 2007 and 2013. Over that period, our overall measure of housing deficiency shows an increase, from 2 to 2.6 million households (a 30 percent increase). This compares to a decline from 1.5 to 1.45 million for the official measure of housing deficit and housing inadequacy combined over the same period (a 3 percent decrease). The seven components of the housing deficiencies indicator evolved as follows:

1- The estimated number of households living in precarious units went from 48,930 to 53,201 (9 percent increase).

2- The estimated number of households without access to basic services went from 691,455 to 519,237 (25 percent decline).

3- The estimated number of households who do not own the land one which their house is built went from 478,205 to 436,250 (9 percent decline).

4- The estimated number of households living in overcrowded condition went from 72,934 to 71,288 (2 percent decline).

5- The estimated number of households with undesired cohabitations went from 154,168 to 122,361 (21 percent decline).

6- The estimated number of households living in tenements went from 12,924 to 20,216 (56 percent increase).

7- The estimated number of households housing and transportation cost burden went from 1,167,785 to 1,905,639 (63 percent increase). 
In response to such situations of housing deficiencies, public policy interventions that enable households to access a better housing than they occupy under current market and institutional conditions can improve social welfare. Such interventions are justified by existing studies establishing the existence of negative externalities associated with the housing deficiencies listed above. These individual and collective costs include the negative effects of poor building conditions, lack of access to services or overcrowding on physical and mental health, and in particular on children outcomes; the negative effects of the instability created by the lack of formal titles or lack of access to jobs on economic productivity; the lack of liquidity in the housing market due to the absence of property registry and housing price information that create transaction costs limiting mobility and the development of the mortgage market; the underinvestment in health and education resulting from high housing and transportation costs relative to income; and the coordination problem associated with delivering and financing urban services in urban areas that developed without them.

Building new units is not necessarily the best response to some of these issues. Other forms of public intervention might include housing vouchers, incentives to strengthen the rental sector, the development of home improvement loans, public infrastructure programs, land title regularization, increased efficiency in issuing building permits, ordinances to facilitate the redevelopment of vacant buildings and enforceable building standards and requirements for new construction. By breaking down the proposed housing deficiencies indicator into seven, it is possible to identify the policy responses that might best address different housing deficiencies and which intervention to prioritize. It is also possible to use the combined housing and transportation affordability indicators as part of the process of identifying places where subsidized housing can be built to benefit most efficiently low and moderate income households. Further data and work to identify housing needs at the sub-metropolitan level and more accurately capture housing and transportation costs is still needed. 


\section{Introduction: Housing Deficiencies: how to define them, how to measure them?}

An important issue facing the Brazilian federal and local governments is housing deficiencies. Brazilian cities at the start of the $21^{\text {st }}$ century have a substantial number of substandard housing units, with informal land tenure and a lack of access to basic urban services. These problems afflict even Brazil's largest and most economically productive metropolitan regions: it is hard not to associate Sao Paulo and Rio de Janeiro with the large favelas in which many of their residents live. This situation is the result of decades of rapid urbanization and population growth, without sufficient new housing and infrastructure construction, due in part to insufficient availability of housing finance instruments, in part to limited local government capacity, and in part to overly restrictive zoning and construction regulations. Brazil's urban population grew from 18.8 million in 1950 to 161 million in 2010. Over the same period, the average household size declined from above 5 to 3.3 (IBGE 2014). In the case of Sao Paulo Metropolitan Region (RMSP), population grew from 2.7 million in 1950 to 19.7 million in 2010 while the municipality of Sao Paulo grew from 2.2 million to 11.3 million residents. (Secretaria Municipal de Desenvolvimento Urbano 2014).

New construction did not keep up with demand. In Sao Paulo municipality, the number of households grew by more than 1 million between 1980 and 2010, increasing from 2.5 million to 3.6 million (Secretaria Municipal de Desenvolvimento Urbano 2014). Over the same period, the number of new formal housing units launched was less than 800,000 , according to exhaustive data collection on new construction collected by EMBRAESP for Sao Paulo municipality (EMBRAESP 2014). This means that not accounting for the attrition of the existing stock, over 200,000 households (or about a fifth of new households) had to find accommodations in the informal sector, often in substandard units lacking access to basic amenities.

Over the last decade, the Brazilian government has implemented a number of initiatives to improve the housing situation of all residents. Brazil's mortgage market, funded through its provident fund administered by the public bank Caixa Economica Federal, started to grow again. The volume of new mortgages increased from less than 150,000 in 2000 to over 1 million in 2010, but housing finance is still largely used for the financing of new units (Haddad and Meyer, 2011). In 2009, the federal government launched the program Minha Casa, Minha Vida, an economic stimulus to increase new construction and facilitate access to homeownership for low and moderate income households. The program features direct subsidies for developers and subsidized mortgage interest rates for households. The interest rates are tied to the households' incomes. These recent developments emphasize new construction for homeownership as a response to existing housing deficiencies and population growth but neglect the development of a robust rental sector and improvement of the existing stock. Owing to the long history of insufficient and substandard housing provision, addressing existing housing deficiencies requires a variety of policy strategies that go beyond new construction. The intervention of governments in housing is justified by the negative individual and social costs associated with poor housing conditions (Rohe et al 2013). Households whose house is made of non-durable materials or who lack access to basic infrastructure services (water, electricity, sewer) or who live in overcrowded conditions have been shown to have worse health, employment and children educational outcomes (Bashir 2002; Cattaneo et al 2009; Krieger and Higgins 2002; Evans 2006). Households who lack proper title to their house or the 
land on which it is built face uncertainty and pay a cost for protection, spending time to defend it, negatively affecting their economic productivity (Brueckner and Lall 2014; Galiani and Schargrodsky 2010; Lall et al 2007). In addition, they have a limited access to credit (de Soto 1990, 2003). Households spending more than a certain share of their income on housing induced expenditures, when these conditions reflect affordability constraints rather than preferences, have also been shown to experience negative outcomes, spending less on education and health, among other services, resulting in decreased human capital and productivity (JCHS 2014). In addition, informal settlements have been shown to have a negative impact on surrounding housing value (Nadalin 2010). Governments have therefore an incentive and role to play in identifying housing deficiencies and developing adequate policy responses in order to improve individual and social welfare. This study is an attempt to propose a robust and stable measure of housing deficiencies that can be used to track progress made over time at the local and national levels in providing every Brazilian with an adequate dwellings.

A number of indicators have been developed to measure housing deficiencies in Brazil. In particular an official measure of housing deficit and inadequate housing was developed in the mid-1990s by the Fundacao Joao Pinheiro (FJP) for a count for the Ministry of Cities, with support from the United Nation Development Program and from the International Development Bank. This measure uses a methodology that has been periodically revisited since (FJP 1995; FJP 2000; FJP 2013) housing deficit counts first began. In the state of Sao Paulo, Fundacao SEADE has developed its own measure of housing needs based on surveys and administrative data. Its definition is more extensive as it includes within the deficit units located in areas with environmental risks, in favelas or with insufficient space (Genevois and Costa 2001; SEADE 2010). Other measures have also been developed by researchers at IPEA, reproducing the work of the Fundacao Joao Pinheiro (Furtado et al 2013) or discussing alternative measures (Gonsalves 1998; de Azevedo and Araujo 2007; de Mirande-Ribeiro et al 2013).

This study aims to contribute to the conversation about housing deficiencies indicators and the way to make them relevant for policy by proposing a single indicator of housing deficiencies that can be broken down into different components based on the policy response they require. Defining housing deficiencies is not a straightforward issue. Are existing housing needs just the difference between number of families and number of housing units? Or should housing needs include units that lack certain physical characteristics, both on site or off? For example, if a house is not connected to sanitation, should it be included in the measure of housing deficiency? If a house is more than an hour away from the nearest job center, should it also be included? How should the absence of affordable housing be considered?

After briefly reviewing the conceptual approach used by FJP in its definition of housing deficiencies in section I, we present seven components which provide the foundation for the establishment of a single measure of housing deficiencies. We take a detailed look at the seven sub-components in section II. Section III implements this proposed definition for the Sao Paulo Metropolitan Region and section IV concludes by discussing possible policy implications and limitations of the proposed measure.

\section{I- Housing deficiencies as officially defined in Brazil}


The Foundation Joao Pinheiro (FJP) was charged by the Ministry of Cities to develop and calculate housing needs estimates for Brazil, individual states, metropolitan regions and municipalities, with the first estimates being released in 1995 based on the 1991 census. FJP broke down the concept of housing needs into housing deficit and housing inadequacy. We focus on the FJP definition since it is the measure used to orient federal policy, including the evaluation of Minha Casa, Minha Vida, which is the main housing program.

The deficit concept aims to capture households living in conditions that require building a new unit, either because the physical structure of the unit they live in cannot simply be improved but requires replacement or because the households experience living conditions deemed substandard and having large negative consequences on their welfare. There were originally two component to the deficit: 1) households living in housing units that were improvised (not designed for residential purposes) or "rustic" defined as those made of unsustainable walls; 2 ) households with more than two families cohabitating (after 2007 only cohabitating families with residents that expressed the desire to move out were considered as part of the deficit) or living in tenements (comodos). A third component was added that captures overcrowded units defined as rental households with more than three persons per bedroom. A fourth component, reflecting lack of housing affordability, was added after 2000 . That component is defined as households spending more than 30 percent of their incomes on rent.

The housing deficit was developed to measure the number of units that need to be built to solve existing deficiencies as well as to meet future demand in light of growth and depreciation of the current stock. The main policy response based on this indicator has been to create programs such as Minha Casa, Minha Vida, whose success is evaluated based on the number of new units the program provides, regardless of whether the new units are located in areas close to jobs and services or whether they fulfill the needs of those who occupied deficient or expensive housing unit before receiving a Minha Casa, Minha Vida unit. The other indicator developed by FJP, inadequate housing, includes housing units with physical deficiencies, such as an inadequate roof, absence of a bathroom, absence of sanitation, or absence of other basic infrastructure (electricity, water canalization, sewer or septic tank, garbage collection). Houses without property title are also considered inadequate, as are owner-occupied houses with more than three persons per bedroom.

Breaking down housing needs into different components tells us more than a single indicator, such as "housing deficit," because different types of housing deficiencies require different types of policy responses. For example, households facing a housing problem may not need a brand new unit; they might simply need resources to improve or enlarge their unit, or to move to a larger unit, liberating their existing unit for a smaller household. Subsidized loans for home improvements, or vouchers that allow people to move to larger units, might be more effective ways to help Brazilians obtain acceptable housing than new unit construction. Issues with the definition of the housing deficit as it currently exists are discussed in the rest of the section.

\section{Departure from the Definition of Housing Deficit by FJP}


We begin with the first component that considers the structural soundness of houses: as it stands, "rustic houses" only includes units with structurally unsound walls. But adequate roofs and indoor sanitation are also costly improvements, and arguably are as important to physical soundness as adequate walls. We propose that houses with inadequate roofs and non-existent sanitation be deemed "rustic."

The definition of undesired cohabitation, the second component of the deficit, was improved after 2007 by the addition of a question in PNAD that asks members of cohabitating households whether they have the intent to form their own households. The introduction of this question aimed to make it possible to distinguish between households who are cohabitating because of preferences (for example, adult children with children of their own might wish to live with their parents in order to receive help with child rearing, or to take care of infirm parents) from those who are cohabitating due to their inability to afford an adequate housing. The ability for this question to capture true preferences rather than to reflect culturally dominant norms remains a potential issue. Nonetheless, the use of this variable led the number of cohabitating households counted toward the housing deficit to decrease from 3.3 million households nationally in 2006 to 2.1 million in 2007. Cohabitation used to be the largest component of the housing deficit; the change in its definition, combined with the worsening of housing affordability (arising from rents rising faster than incomes), has led to its falling to the number two contributor to the deficit. We do not suggest any change to this variable.

Overcrowding was not part of the original definition of deficit but was included in the definition of inadequate housing until 2006. Renter households with more than three persons per bedroom are now counted as part of the housing deficit. The distinction between renters and owners household with regard to overcrowding seems problematic. The allocation of overcrowded renter households to the deficit and of overcrowded owner households to the inadequate housing measure is justified by FJP by the fact that potentially owners could expand their dwelling to respond to this situation. This rational seems limited by owner financial and physical capacity to expand. For example, owners of apartment do not have the capacity to expand. Owners of single family houses may occupy small lots or not have access to housing finance; both of these possibilities are impediments to expansion. It seems that for both renters and owners, living in overcrowded conditions reflects a housing affordability problem-households have insufficient income to consume housing sufficiently large to not compromise physical and mental health. We propose to combine rental and owner overcrowded households as the negative externalities associated with overcrowding are not expected to differ by tenure type.

The fourth component, housing affordability was also not included in the original definition of housing deficit, but it has now become the leading contributor to the definition. While recognizing that 30 percent of income is used as an affordability threshold in a number of studies and in official indicators, there are a number of conceptual difficulties associated with this indicator as part of the housing deficit:

- The first issue has to do with the universe on which the measure of housing affordability developed by FJP is based. First, the definition only includes net rent and does not include utilities, property taxes or condo fees (property taxes and condo fees are often paid by the tenant in Brazil). Second, only 20.5 percent of RMSP residents and 17.9 percent of the overall Brazilian population were 
renters as of 2013 (Figure 1 and PNAD 2013). Renter households are also often households in transition periods (young households recently married waiting to purchase an apartment, temporary movers, or recent movers to a city). The measure would be better if it included households who are paying more than 30 percent of their income on mortgage payments, even if only a small share of the population uses mortgages (this despite a rapid increase in the use of credit since 2004) ${ }^{1}$. But the real issue with restricting the universe to renters is that these households are not necessarily those who are not able to afford to buy. Among families in the lowest income decile, 64.6 percent own their dwelling free and clear in RMSP as of 2013. Those households often own their residences through self-building on invasion parcels. Not accounting for these households in the measure of affordability is an issue. These households are living in self-built informal units in part because they would not be able to afford owning or even renting in the formal sector. Brazilian official surveys do not regularly ask households about the self-assessed value of their house and there is no national public property record containing transaction prices. This information is not systematically collected by private firms either, and as a result it is difficult to estimate housing expenditures for these households. We discuss alternative proposals to capture housing expenditures for households who own their house in full in the next section but it is important to recognize that these household do not live rent free. The universe is also limited to household earning less than three minimum wage ( $R$ \$2,172 as of 2014 or about $\$ 970$ ). Households above this threshold who spend more than 30 percent of their income on rent are probably more likely to just prefer spending money on housing, rather than other things. The choice of three minimum wage as a threshold at which people are choosing their level of housing expenditure could be justified if there were evidence that above this income level households who spend more than 30 percent of their income on housing do not spend less on other essentials, such as health and education.

- The second issue is more conceptual: using housing expenditures alone to determine affordability, without controlling for housing or neighborhood quality, or location, results in an apples to oranges comparisons between households. When deciding on its housing situation, a household chooses a bundle of services (size and quality of the housing unit, but also neighborhood quality, access to jobs, amenities). As such, it is possible that a household spending 31 or even 40 percent of its income on housing in order to live close to jobs, in a neighborhood with great access to health, education services or with great consumer amenities, has higher welfare than a household spending 29 or even 20 percent of its income on housing that is located far from jobs, in a neighborhood with poor quality schools and hospitals. One standard way to control for location differences is add together housing and transport costs, because transport cost is very much associated with the location of a housing unit. This is consistent with the classical spatial equilibrium model developed by Alonso (1964), Mills (1967) and Muth (1969), in which house costs vary based on access. The upshot is that households spend a different share of their incomes on housing, but equal shares on the sum of transport and housing. Under such circumstances, households will be indifferent to location. More sophisticated housing affordability indicators use hedonic regression models to develop constant quality indicators that account for the variations in the quality of amenities over space (Fisher et al. 2009). We propose in

\footnotetext{
${ }^{1}$ Only 7.0 percent in RMSP and 5.2 percent in Brazil overall as of 2013 use mortgages to finance their houses.
} 
the next section to develop a measure that captures both monetary and time value costs of commuting to create an indicator that combined housing and transportation costs.

- The third definitional issue arises from the problem of using any arbitrary threshold. An issue arises when we argue that each household paying 31 percent of their income on rent contributes to the deficit (and therefore requires a new unit) while households paying 29 percent of their income on rent do not require any action at all. It might be conceptually more appropriate to use housing price elasticity to identify how many new units are needed, keeping demand constant, to bring prices to a level that would be affordable to all households. In addition, 30 percent of gross income might not be the correct threshold for all households. It is likely that very low income households do not even have 30 percent of their income left once accounting for food expenditure necessary to cover the nutrition needs of each of their household members. Considering a measure based on available income after basic nutrition needs are met might be more appropriate for determining how much disposable income different households can afford to spend on housing.

\section{II- A single measure of housing needs, different policy responses}

Our goal in adding to the extensive work on housing needs metrics that already exists is to be able to propose an indicator based on a comprehensive definition of housing needs that: (1) uses reliable and consistent data that (2) can be tracked over time, first for Sao Paulo Metropolitan Region and eventually nationally. We also try to identify possible policy solutions that vary depending on the category of needs.

For now, we work with currently available data, but we also identify data that do not currently exist but that would, if available, allow us to build a stronger indicator of housing needs. The measure of housing need we developed is an attempt to capture (1) the number of units that require some forms of physical interventions or (2) the number of households who need to be assisted financially in order to stabilize financially their housing situation. Such public interventions are based on a social welfare improving policy goal to minimize the negative individual and social welfare effects associated with substandard housing conditions.

The units in which the households identified as having housing deficiencies live do not necessarily need to be demolished and replaced with new units. But the households/units we identify as problematic require some intervention. Much progress has already been made over the last decades in addressing the most immediate housing needs of households living in dwellings made of non-durable materials, or that lacked access to basic services such as water and electricity. As of 2013, in PNAD sample for RMSP, less than 1 percent of households lives in non-durable dwellings or do not have access to water and none do not have access to electricity. Nonetheless, beyond these very elementary needs, there are still many households whose housing conditions are unsatisfactory and require some form of government intervention to bring them up to adequate standards.

We have identified seven housing situations that require some form of intervention, each potentially requiring a different kind of policy response. These categories are based on an existing measure of 
housing needs in Brazil, including the concepts of housing deficit and inadequate housing as well as UN Habitat work on defining housing needs:

- Precarious units, those are defined as units that require some structural improvements or to be replaced by new units built to a higher standard. Counted as precarious are: units classified as improvised by IBGE (units that are not destined to be used for housing: office space, warehouses,...), units whose wall or roof construction materials are not durable (this includes walls made of straw, uncoated rammed earth, and harnessed wood and roofs made of harnessed wood, straw or other materials) and units that lack indoor bathroom and/or sanitation. The difference with the definition of rusticos as counted toward the housing deficit by FJP is that we include units with non-durable roofs (made of harnessed wood, straw or other materials) and units that lack bathroom or sanitation. The rational is that bringing such units to a minimum standard would require significant investments that are of a similar magnitude to redoing the walls.

- Policy responses can include providing small, subsidized loans to households to make home improvements, encouraging new construction with decent standards. These programs are mostly individual based, with limited need for collective action. The government can play a role in providing programs to jump-start home improvement loans, currently not being offered in Brazil, and in setting construction standards that are enforceable.

- Units that lack access to basic infrastructures, generally requiring some coordinated intervention at the neighborhood level to connect them to networks. These units are identified as those that lack: access to sewer (and do not have septic tank); water canalization inside the unit; electricity; and trash collection. While all these dimensions are part of the definition of inadequate housing, it is not part of the definition of the housing deficit by FJP. They are included as an indicator of housing need because lack of access to basic infrastructure has long-term negative impacts on individuals.

- Policy responses can include infrastructure development programs based on PublicPrivate-Partnerships to deliver infrastructure in a timely and cost-efficient way, local infrastructure bonds to fund infrastructure investments, increased use of development fees to internalize the costs of providing infrastructure to new developments. These are mostly collective neighborhood level initiatives that require the involvement of the local or federal governments.

- Units whose occupants lack property titles, defined as owner households who declare they do not own the land on which their house is built. Households living without an official land title even if not at immediate risk of eviction face a number of limitations in accessing services and in using their home as collateral for loans.

- Policy responses can include coordinated land titling programs joint with the development of a functioning property registry that can be made public. The first order effect of land titling is to ensure household stability of tenure and ability to use houses 
as collateral. The second order effect is to contribute to the liquidity of the housing market by increasing access to information about property value. Having information about house value, transaction volumes, and price changes decreases frictions in the housing market, reduces transaction costs and increases the ability of households to buy and sell their homes.

- Undesired cohabitations, generally linked to housing affordability and requiring increased housing supply and/or subsidies. These units are identified as those where members of cohabitating families express their desire to form their own households. In PNAD 2007, IBGE introduced a question asking members of cohabitating families whether they have the intention to move and form their own household. This enables a distinction among cohabitating families that better separates constrained housing choices from preferences for cohabitation. We follow here the definition of FJP.

- Policy responses can include stimulating housing supply by facilitating the delivery of building permits, enabling higher density development (smaller unit size), developing subsidy schemes to enable access to financing for developers and for households but also potentially providing some (rental) housing vouchers since this is in part an income issue, with workers earning less than three minimum wage having little discretionary income left after accounting for the cost of basic necessities such have food. Reforming floor-area-ratio maximums in areas with good access to jobs and transportation might help create more units near employment centers and other amenities, and might also relieve the tendency toward undesired cohabitation.

- Overcrowding, is also linked to housing affordability and requires increased housing supply and/or subsidies. These units are identified as those with more than two residents/room. The main difference with the FJP definition of housing deficit comes from the fact that we do not distinguish between the forms of tenure. In addition, the threshold is calculated by room rather than by bedroom and established at three residents per room rather than four per bedroom. If there are more than two residents per bedroom whether the household owns or rents his property, we consider it as being a situation of housing need.

- Policy response: same as for undesired cohabitation, as this is largely a manifestation of affordability constraints and an absence of supply in desirable locations.

- Tenements, defined by the census as comodo, generally single room occupancy units with households sharing a bathroom and kitchen with other households, either as a result of subdivided single family houses or in tenement buildings.

- Policy response: all these buildings do not necessarily need to be demolished and rebuilt, it might be possible to convert them to larger units, with adequate amenities. Targeted loans to encourage owners to invest in their properties might be effective. A concern is to avoid the disappearance of what amounts to an affordable housing option in the process. 
- Excessive housing cost burden, directly linked to housing affordability and income inequality. Requires increased housing supply and/or subsidies to limit the share of their budgets households are forced to spend on housing to afford a decent dwelling. Excessive housing cost burdens are the result of unaffordable housing costs relative to income. It becomes a public issue because those households are not merely revealing a preference to consume a large share of their income on housing services but rather are constrained to spending such a large share of their income on housing because of supply constraints that limit the availability of adequate dwelling they can afford while spending their preferred share of their income on housing. As a result these households are faced with trade-offs such as decreasing their spending on health or educational expenditure, creating large negative externalities.

The housing deficit measure defined by FJP defines excessive housing cost burden as rental households earning less than three minimum wage whose rent (which might or might not include some utility payments) represents more than thirty percent of their income. This measure has a number of issues, the most important of which is its absence of considering the 80 percent of RMSP residents who are not renters. Many of the metropolitan region lower income households relied on saving and self-building to construct their own dwelling, often without title to the land, without proper permits and with limited access to amenities, because they could not afford anything better. Many of these households are not well-served by the current housing market.

We propose to identify excessive housing cost burdened households as all households (either renter or owner) who are spending more than 30 percent of their income on housing expenditure or more than 45 percent of their income on housing and transportation expenditures. Combining housing and transportation expenditure is not part of traditional housing affordability measures (Green 1996; Stone 2006; Joice 2014). Housing affordability measures such as price to income and rent to income ratios were generally developed at the metropolitan level to track the evolution of market fundamentals. These measures make it possible to identify whether a market is becoming more or less affordable and if the median households in this market is housing cost burden. Focusing on housing solely avoids confounding the evolution of housing and transportation costs and facilitates comparison across metropolitan regions. Including transportation costs has emerged in the US as a valuable addition, complementing traditional housing affordability indicators. The US Department of Housing and Urban Development has adopted such a combined measure called the Location Affordability Index (LAI). Modeled on the Center for Neighborhood Technology (CNT) H+T Index, the LAl measures the share of income different household types spend on housing and transportation combined the neighborhood level. In the US context, CNT puts the point at which housing and transportation costs become excessive relative to income at 45 percent. In their measure, they compute only the monetary costs of transportation, not travel times (HUD 2014). A measure based on this concept was developed for Beijing (Zheng et al 2011).

Combining housing and transportation costs is consistent with the classical urban model developed by Alonso (1964) and extended by Mills (1967) and Muth (1969). In the spatial equilibrium model, housing costs plus transportation costs are constant across space within a metropolitan area. For households, the main trade off is between the quantity of housing services consumed and transportation costs to 
access their jobs (both monetary and time value). In equilibrium, households are indifferent between spending more on housing and less on transportation or more on transportation and less on housing. The utility of a household located in the center, close to jobs and therefore with limited transportation costs but higher housing costs is therefore identical to the utility of a similar household located further from the center, having lower housing costs but facing higher commuting costs. The utility of these two households being identical, a measure of affordability needs to capture them as observationally identical. Only accounting for housing costs, the first household would appear as being worse off than the second one, which is clearly incorrect. Once transportation cost is added to housing cost, however, they should have the same expenditures for the same level of utility. In RMSP, access to jobs and high quality services are largely limited to the center resulting in long commutes for households living on the periphery (particularly to the South and East) who are also more likely to face high levels of deprivation (Figure 2 and 3). Combining housing and transportation expenditures is therefore a parsimonious way to capture constant quality housing expenditure. We therefore attempt to develop a measurement of housing cost burden that is based on combined housing and transportation expenditures.

The six first dimensions of housing needs can be directly obtained from variables available in most public surveys conducted by the IBGE (PNAD or decennial census). In order to identify the seventh dimension, households who are cost burdened, we need to estimate housing and transportation expenditures. Doing so in the Brazilian context presents a number of difficulties. As mentioned earlier, as of 2013, in RMSP 21.4 percent of households are renters, 7 percent are owners with a mortgage and 64.9 percent own their dwellings in full (6.7 percent are living in other form of tenure, and are mostly households whose housing is provided by their employer or for free by relatives or friends). PNAD and the decennial census collect information about the rent paid and the amount of mortgage payments but only POF has detailed information about utility and transportation expenditures. None of these public surveys have the information about house value necessary to develop an estimate of user costs for households who own their houses without a mortgage. In addition, there is no comprehensive and reliable property transaction record, either at the metropolitan or at the national level.

In order to estimate plausible housing expenditures for households who own their house in full, the literature offers three approaches:

- The user cost approach based on amortized cost of purchasing a given property in current conditions using assumptions regarding financing, maintenance costs, appreciation. This approach is grounded in economic theory and has been used extensively in the academic literature (Hendershott and Slemrod 1982; Green 1996), including in emerging countries (Malpezzi and Mayo 1987): we cannot apply it without having access to house value

- The construction cost approach based on amortizing the building cost over the life of a property. This approach is regularly used, notably in the industry (McKinsey 2014). It requires having estimates of construction costs for different building types, estimated useful life of the building, and property characteristics such as size and quality of units that are not available in Brazil.

- The owners' equivalent rent (OER) approach based on the estimated rent an owner occupied unit would fetch in the market (Crone et al 2004; Poole et al 2005). This can be calculated by asking owners how much they believe their unit would rent for in the market (as is done by the 
Bureau of Labor Statistics in the US as a component of the Consumer Price Index). It can also be calculated using hedonic regression models predicting the rent an owner occupied property would fetch based on its observable characteristics (size, number of rooms, bedrooms, bathrooms, access to infrastructure, location) following Rosen (1974). Such an approach regresses rent on a number of characteristics and applies the estimated coefficients for rental units to owned units. It is possible to do this analysis for RMSP, as PNAD contains a detailed list of housing characteristics, and the rent variable is considered by census officials to be reliable. The main limitations in the public data are the lack of a precise measure of the size of each unit and, most important, of the location of the units in as well as the lack of information about access to amenities. ${ }^{2}$ Another limitation is that rental units can differ systematically from owned units in their attributes, resulting in poor out of sample predictions, but in the case of RMSP, rental and owner occupied units appear relatively similar in terms of observable characteristics (Table 1). In light of the data that are available, the hedonic approach to attributing rent to owner units seemed like the best approach to determining the extent to which households in Brazil are "house rich and cash poor."

[Table 1]

- In order to estimate transportation expenditures, we need to estimate the monetary cost and the opportunity cost of commuting. For the monetary cost, we use information on time of travel to first job available in PNAD and impute transportation cost as being the monthly transit costs within Sao Paulo municipality for households whose commute is longer than $\mathbf{3 0}$ minutes. The reliance on transit cost within Sao Paulo municipality as the reference category is likely to underestimate the cost for households commuting by transit from outside Sao Paulo or commuting by car or motorcycle. It is likely to overestimate the cost for households commuting by feet or bike but we do not have information in PNAD about mode of transportation to provide a more precise estimate. In addition, Brazil's "vale transporte" requires employers to provide a subsidy so that employees do not spend more than 6 percent of their salary on commuting cost, we therefore cap monetary cost to 6 percent of income. This is conservative given that this program only applies to formal employees and it is estimated that "about 40 percent of the employed urban poor are either self-employed or work in the informal sector" (Carruthers et al 2005) and therefore do not benefit from this program. For the opportunity cost of transportation we use the PNAD variable on commuting time and multiply it by the worker's hourly wage (both only capture the first job, but as of 2013, less than 2 percent of workers have a second job). Because PNAD's commute time variable is categorical, we use the mid-range point for all categories except for the highest that is unbounded and for which we use the lower bound. Using the mid-range point is likely to overstate slightly transportation time as the distribution of observations is skewed to the left but the use of the lower bound for the upper category understates the length of commute for these workers.

\footnotetext{
${ }^{2}$ We are in the process of submitting a request to IBGE in order to have access to the detailed location (at the census tract level) of individual observations to improve our OER estimates.
} 
- Policy responses: addressing affordability issues is complicated. The current focus of Brazilian housing policy on ensuring access to ownership even if that means building far from job centers and urban services does not appear to be sustainable. A balanced approach with a mix of affordable rental and ownership options is preferable. The interventions are similar to those to address undesired cohabitations: improve the efficiency of the housing permit process, allow higher densities, facilitate the redevelopment of vacant building for residential purposes and develop subsidy schemes for rental housing with an added emphasis on housing vouchers. In addition it is important that affordable housing programs focus on infrastructure development and emphasize the need to locate new housing developments close to jobs and infrastructures, especially in the case of projects receiving public subsidies such as those who are part of MCMV.

Looking at each component of the overall measure of housing needs is important since the adequate policy responses vary depending on the dimensions. The conceptual measure of housing deficiencies developed here has seven dimensions: precarious units, units lacking access to infrastructure, units lacking land title, undesired cohabitations, overcrowded conditions, tenements and excessive housing cost burdens. As discussed above, the first six dimensions are derived from the existing definitions of housing deficit and inadequate housing by FJP. Changes in the definition at the margin aim to capture situations of housing needs based on the policy interventions they require. The measure of the number of households experiencing each of these dimensions can be implemented for all Brazilian metropolitan regions and states using the data available annually in PNAD (and in the Census by imputing the value for undesired cohabitating households). The implementation of estimates of the seventh dimension, a combined measure of housing costs and transportations costs relative to income, is more complicated to estimate and remains problematic due to data limitations.

\section{III- Housing needs in Sao Paulo Metropolitan Region: evolution over time}

In order to test this proposed measure of housing needs, we use PNAD data from 2007 to 2013 for RMSP to estimate the changes in housing needs overall and for each of the seven dimensions over that period. We also compare our estimates to the existing estimates of housing needs as captured by FJP housing deficit measure. Table 2 lists the variables from PNAD used to calculate the different indicators of housing needs. Table 3 reports our estimates and our computation of the deficit using the official definition. PNAD is an annual national survey conducted by IBGE. For RMSP, each survey contains about 8,000 housing units with information about the units and its residents, enabling precise estimates of housing needs. The stratified structure of the survey means that units are sampled only from a limited number of municipalities every year, which can explain some of the annual variation from year to year, depending on the municipalities that were randomly sampled, but multi-year trends are meaningful.

Owner equivalent rents for owner occupied properties are calculated using a hedonic approach to estimate rents, and use the coefficients obtained to predict the rent owner occupied properties would fetch based on their physical characteristics and access to services. As discussed above, hedonic models have been extensively used to estimate rent, including in Brazil (see for example Morais and Cruz 2003 and Reiff and Barbosa 2005). 


\section{[Table 2]}

In order to obtain Owner's Equivalent Rent estimates, we estimate the following Weighted Least Square model for permanent rental units in Sao Paulo metropolitan region. We use the log of monthly rent as the dependent variable and the number of rooms, the building type, having a bathroom, wall and roof materials, sewer access, garbage collection and commuting time for workers in the household as explanatory variables:

$$
\begin{aligned}
\log \left(\text { Rent }_{i}\right)= & \alpha+\beta_{1} \text { Room }_{i}+\beta_{2} \text { BuildingType }_{i}+\beta_{3} \text { Bath }_{i}+\beta_{4} \text { Wall }_{i}+\beta_{5} \text { Roof }_{i}+\beta_{6} \text { Sewage }_{i} \\
& +\beta_{7} \text { Garbage }_{i}+\beta_{7} \text { CommuteTime }_{i}+\varepsilon_{i}
\end{aligned}
$$

This model explains between 48 and 61 percent of the variance in rents, the signs of the coefficients are generally in the expected direction and the residuals do not reveal the presence of significant levels of heterodeskasticity (Appendix 1). Therefore, despite the lack of key locational characteristics, the model's predicted rent appears to be reliable. We apply the coefficients obtained in the rental model (see appendix 1) to owner occupied properties to produce Owners' Equivalent Rent estimates, but in order to account for the fact that owners are getting these housing services while owning their dwelling free and clear, we also add the OER to the denominator as income when calculating the housing cost to rent ratio. As a result, the housing cost burden for owners is equal to: OER/(Monthly Income + OER).

[Table 3]

Our results show an overall increase in the number of households who are experiencing at least one sort of housing deficiency from 2.0 million in 2007 to 2.6 million in 2013. This increase in absolute number translates in an increase in the share of households who are in that situation from 34.9 percent to 38.8 percent. While there are year to year variations in the indicators and its component, the trends of an increase in the number of households experiencing some form of housing deficiency appears relatively consistent over the brief period studied. Despite having experienced a period of rapid economic growth, and the implementation of a number of ambitious policies, the metropolitan region of Sao Paulo is not showing progress toward reducing the number of households living in substandard conditions.

That said, the overall increase in the number of households experiencing needs to be broken down into its component has progress has been made on a number of dimensions. Most notably, the number of households living in housing units that lack basic services has decreased from 690,000 to 520,000, a 25 percent decrease. In addition, the number of households living in precarious units, in situation of overcrowding, of forced cohabitation or declaring that they lack title also decreased. In contrast, the overall increase was driven by a large increase in the number of households who are being burdened by the share of their income they allocate to housing and transportation expenditure combined. The number of households in this situation increased by 700,000 from 1.2 to 1.9 million, now representing 28.3 percent of all households compared to around 20.3 percent in 2007.

Using the official definition for the housing deficit measure, the number of households in situation of housing needs also increased, from 553,000 to 613,000 over that period, essentially due to an increase in the number of rent burden households. The definition of housing affordability developed in this 
report and the inclusion of units lacking access to services or land title are the main sources of the large difference between our proposed measure of housing deficiency and the official measure of housing need. While the evolution of these two sets of variables evolved in different direction, they contribute to explain that our estimated overall housing deficiency measure is several orders of magnitude larger than the official housing deficit measure.

The measure of units lacking access to services and title is currently included in the official measure of inadequate housing but not in the measure of housing deficit that is the most widely used figure to orient housing policies as demonstrated in official presentations of the Minha CasaMinha Vida project or in newspaper account of Brazil's housing needs. Integrating units lacking access to basic services or title to an overall measure of housing needs contribute to maintain the focus on this issue. And the data available enable a robust measure of the number of housing units experiencing these situations.

Nonetheless, when including the measure of inadequate housing, the official measure of housing needs for Sao Paulo Metropolitan Region actually decreased during the 2007-2013 period from 26.2 to 21.7 percent of the population due to the absolute number of inadequate units decreasing from 954,000 to 846,000 over that period.

Housing affordability issues are likely as important to improving household welfare in Brazil, especially in large metropolitan regions such as Sao Paulo that is the focus of this study. While robust indicators of housing affordability have been conceptualized and operationalized in a number of countries, the data currently available in Brazil to adequately measure housing affordability is limited. Less than one quarter of households being renters, it is necessary to develop a measure of housing affordability for owners. Given the current lack of access to a universe of property value data that would allow an estimation of neighborhood level or individual level housing prices, the owner equivalent rent is the only possible approach. The approach taken here allows accounting for the trade-off faced by owner-occupied households by estimating their imputed rent equivalent. There are a number of issues with this approach as discussed in the previous section, the main one having to do with the locational controls available to estimate the imputed rent. Developing the datasets to establish property value and track them over time is essential to the development of more robust housing affordability measures. In addition to including owners, our measure of affordability expends on existing indicators by including transportation costs that are location specific and contribute to constrain the budget of households that are located far from job centers. Additional controls for differences in amenities could be added if the data is available, but transportation costs and housing costs combined capture an important proportion of the location choices made by individual households.

There are important limitations to the measure of housing affordability we developed. Despite these limitation, it makes clear that capturing adequately who these households are, where they are located and what solutions can be provided to their housing needs is essential in order to address Sao Paulo's housing needs going forward as the number of affordability constraints households has increased rapidly in the recent period. Addressing the needs of household that lack access to basic services and land title remains an important issue that needs to be addressed locally through targeted place-based intervention. But addressing the issue of housing affordability is increasingly important and measures to address it need to take into account the location of jobs, urban services. It is important that policies 
targeted at improving affordability offer a variety of housing options: affordable and market rate rental units as well as ownership opportunities, the former being historically neglected by Brazilian housing policies that still predominantly focus on the later.

\section{Conclusion: Can housing deficiency indicators inform policy?}

The number of households living in inadequate conditions has increased between 2007 and 2013 in Sao Paulo metropolitan region, but this evolution masks divergent evolutions in the seven components of the proposed housing deficiency indicator. The number of households for whom rent or rent equivalent and transportation costs combined represent more than 45 percent of their income has dramatically increased over that period as housing prices have increased faster than income (as tracked by a number of indices for the formal sector). At the same time, the number of households experiencing the following housing deficiencies: precarious housing, lack of access to basic services, lack of land title, overcrowding or non-desired cohabitation conditions has declined.

The indicators of housing deficiency developed in this paper aim to capture a variety housing situations that require some form of interventions. In order to be useful and informative for designing housing policies, it is necessary to be able to prioritize which ones among the units classified as requiring interventions represent most immediate needs due to the social costs they generate and what type of policy can address these needs. Estimating that such a large share of households is facing some form of housing needs is not inherently useful. It can make the problem seem unsolvable. In this regards, one of the benefits of the housing deficit estimates produced by FJP is that they can be translated into new construction goals that aim to solve the existing deficit within one decade. At the same time, there is a limit to the approach that equates addressing housing needs to building more units, with the idea that one new unit built no matter its location, in excess of the number needed to respond to natural household growth, means that the deficit has been reduced by one unit. In our estimates, if a new unit is not connected to basic services or not located in proximity to jobs, or its price is too high, this new units can add to the housing deficiency measure rather than contribute to solve it. This can serve to focus the attention of policy-makers to other housing programs ranging from initiatives to develop a more robust rental sector through vouchers and tax incentives to actions to encourage the redevelopment of currently vacant buildings, subsidies and loan programs to improve existing units that are precarious or lack basic amenities and interventions to connect existing units to infrastructures and regularize those that lack property title.

This reports looks at changes in the prevalence of different forms of housing deficiency over a brief period. Even during that period it is apparent that different components evolve in different directions and are likely to require different forms of interventions. Further work needs to be done to refine what policies might be most effective in addressing individual components of the housing deficit. The availability of additional administrative or privately provided data about the distribution of house prices for the entire housing stock, including the informal sector, is also needed to develop more robust indicator of housing affordability that would enable researchers and policy makers to design more targeted housing policies and evaluate their effects on affordability. 


\section{References}

Alonso, William (1964) Location and Land Use. Cambridge: Harvard University Press.

Bashir, S. A. (2002). Home is where the harm is: inadequate housing as a public health crisis. American Journal of Public Health, 92(5), 733-738.

Brueckner, J. K., \& Lall, S. V. (2014). Cities in Developing Countries: Fueled by Rural-Urban Migration, Lacking in Tenure Security, and Short of Affordable Housing. Evans, G. W. (2006). Child development and the physical environment. Annu. Rev. Psychol., 57, 423-451.

Carruthers, R., Dick, M., \& Saurkar, A. (2005). Affordability of public transport in developing countries. World Bank, Washington, DC

Cattaneo, M. D., Galiani, S., Gertler, P. J., Martinez, S., \& Titiunik, R. (2009). Housing, health, and happiness. American Economic Journal: Economic Policy, 75-105.

Crone, T. M., Nakamura, L. I., \& Voith, R. (2004). Hedonic estimates of the cost of housing services: rental and owner-occupied units.

de Azevedo, S., \& Araújo, M. B. (2007). Questões metodológicas sobre o "déficit habitacional": o perigo de abordagens corporativas. Cadernos Metrópole. ISSN (impresso) 1517-2422;(eletrônico) 2236-9996, (17).

De Mello Franco, F. (2013). Sao Paulo: Redes e Lugares. Secretario de Desenvolvimento Urbano.

de Miranda-Ribeiro, A., de Mattos Viana, R., \& Salis, R. M. (2013). Déficit Habitacional no Brasil em 2007 e 2008: notas metodológicas e principais resultados. Geografias (UFMG), 9(1), 97-115.

De Soto, H. (1990). The other path: The invisible revolution in the third world.

De Soto, H. (2003). Mystery of capital: why capitalism triumphs in the West and fails everywhere else. Basic books.

Fisher, L. M., Pollakowski, H. O., \& Zabel, J. (2009). Amenity-Based Housing Affordability Indexes. Real Estate Economics, 37(4), 705-746.

Fundação João Pinheiro (FJP). (1995). Déficit habitacional no Brasil. Belo Horizonte, Projeto PNUDSepurb/92/013, 1995

Fundação João Pinheiro (FJP). (2002). Déficit habitacional no Brasil 2000. Belo Horizonte, Informativo CEI.

Fundação João Pinheiro (FJP). (2013). Déficit habitacional Municipal no Brasil 2010. Belo Horizonte, Informativo CEl. http://www.fjp.mg.gov.br/index.php/docman/cei/deficit-habitacional/216-deficithabitacional-municipal-no-brasil-2010/file

Furtado, B. A., Lima Neto, V. C., \& Krause, C. (2013). Estimativas do déficit habitacional brasileiro (20072011) por municípios (2010). Brasília, DF: IPEA.

Galiani, S., \& Schargrodsky, E. (2010). Property rights for the poor: Effects of land titling. Journal of Public Economics, 94(9), 700-729. 
Genevois, M. L. B. P., \& Costa, O. V. (2001). Carência habitacional e déficit de moradias: questões metodológicas. São Paulo em Perspectiva, 15(1), 73-84.

Gonçalves, R. R. (1998). O déficit habitacional brasileiro: um mapeamento por unidades da federação e por níveis de renda domiciliar.

Green, R. K. (1996). Should the stagnant homeownership rate be a source of concern?. Regional Science and Urban Economics, 26(3), 337-368.

Haddad, E., Meyer, J. F. P. (2011). "The financial crisis and Brazil's expanding housing market." In: Ashok Bardhan; Robert Edelstein; Cynthia Kroll. (Eds.). Global housing markets: Crises, Policies, and Institutions: Wiley - Kolb Series in Finance - Essential Perspectives, v. , p. 491-510.

Hendershott, P. H., \& Slemrod, J. (1982). Taxes and the User Cost of Capital for Owner-Occupied Housing. Real Estate Economics, 10(4), 375-393.

HUD. (2014). Location Affordability Portal: Understanding the Combined Cost of Housing and Transportation. http://www.locationaffordability.info/lai.aspx

IBGE, 2014 Censo Demográfico 1950/2010.

http://seriesestatisticas.ibge.gov.br/series.aspx?vcodigo=CD91

Joice, P. (2014). Measuring Housing Affordability. Cityscape: A Journal of Policy Development and Research, 16(1).

Krieger, J., \& Higgins, D. L. (2002). Housing and health: time again for public health action. American journal of public health, 92(5), 758-768.

Lall, S. V., Wang, H. G., \& Da Mata, D. (2007). Do urban land regulations influence slum formation? Evidence from Brazilian cities. Brazilian Association of Graduate Programs in Economics.

Malpezzi, S., \& Mayo, S. K. (1987). The demand for housing in developing countries: empirical estimates from household data. Economic Development and Cultural Change, 687-721.

Mckinsey. (2014). A Blueprint for Addressing the Global Affordable Housing Challenge. http://www.mckinsey.com/ /media/McKinsey/dotcom/Insights\%20and\%20pubs/MGl/Research/Urbani zation/A\%20blueprint\%20for\%20addressing\%20the\%20global\%20affordable\%20housing\%20challenge/ MGI\%20Affordable\%20housing_Full\%20report_October\%202014.ashx

Mills, Edwin S. (1967) “An Aggregative Model of Resource Allocation in a MetropolitanArea," American Economic Review 57(2): 197-210.

Morais, M. D. P., \& Cruz, B. D. O. (2003). Demand for housing and urban services in Brazil: a hedonic approach.

Muth, Richard (1969) Cities and Housing. Chicago: University of Chicago Press.

Nadalin, V. G. (2010). Três ensaios sobre economia urbana e mercado de habitação em São Paulo (Doctoral dissertation, Universidade de São Paulo).

Poole, R., Ptacek, F., \& Verbrugge, R. (2005). Treatment of owner-occupied housing in the cpi. Federal Economic Statistics Advisory Committee (FESAC) on December, 9, 2005. 
Rohe, W. M., Van Zandt, S., \& McCarthy, G. (2013). The social benefits and costs of homeownership: A critical assessment of the research. The affordable housing reader, 196-212.

Secretaria Municipal de Desenvolvimento Urbano. (2014). População Recenseada

Stone, M. E. (2006). A housing affordability standard for the UK. Housing Studies, 21(4), 453-476.

Região Metropolitana de São Paulo. www.infocidade.prefeitura.sp.gov.br

Reiff, L. O., \& Barbosa, A. L. (2005). Housing stock in Brazil: estimation based on a hedonic price model. BIS Papers, (21), 257.

SEADE. (2010). Necessidades Habitacionais no Estado de São Paulo.

http://www.cdhu.sp.gov.br/download/peh_necessidades_habitacionais_no_estado_de_sao_paulo.pdf

Zheng, S., Liu, K., \& Sun, W. (2011). Affordability Index for Transportation and Housing: An Application in Beijing. Urban Studies, 2, 54-61.

Not used currently:

Kutty, Nandinee K. "A new measure of housing affordability: Estimates and analytical results." Housing policy debate 16.1 (2005): 113-142. 
Tables and Figures

Table 1: Rental and Owner Occupied Units Characteristics in RMSP, 2013

\begin{tabular}{lcr}
\hline & Owners & Renter \\
\hline Number Resident/Unit & 3.08 & 2.97 \\
Median HH Inc. (R\$) & 2,678 & 2,200 \\
Number Room/Unit & 5.74 & 4.52 \\
Sewer & $93.6 \%$ & $96.7 \%$ \\
Garbage Collection & $94.3 \%$ & $96.7 \%$ \\
Bathroom & & $98.9 \%$ \\
\hline House & & $76.7 \%$ \\
Apartment & $76.6 \%$ & $22.7 \%$ \\
\hline Comodo & $23.1 \%$ & $0.6 \%$ \\
\hline & $0.2 \%$ & \\
\hline
\end{tabular}

Source: IBGE, PNAD 2013 
Table 2: Variables Used

\begin{tabular}{|c|c|c|}
\hline Proposed & Variable Name & Variable Number \\
\hline \multirow[t]{4}{*}{ Precarious } & Improvised & V0201 \\
\hline & Wall & V0203 \\
\hline & Roof & V0204 \\
\hline & Bathroom & V0215 \\
\hline \multirow[t]{4}{*}{ Lack Services } & Electricity & V0219 \\
\hline & Piped water & V0213 \\
\hline & Sewage & V0217 \\
\hline & Garbage collection & V0218 \\
\hline Lack Title & Do not own land & V0210 \\
\hline Overcrowding & Density (resident/room) & V0105/V0205 \\
\hline Cohabitating & Intention to move and form own household & V0410 \\
\hline Tenement & Comodo & V0202 \\
\hline \multirow[t]{11}{*}{ Housing } & Tenure & V0207 \\
\hline & Monthly rent & V0208 \\
\hline & Number of room & V0205 \\
\hline & Number of bedroom & V0206 \\
\hline & Wall & V0203 \\
\hline & Roof & V0204 \\
\hline & Bathroom & V0215 \\
\hline & Electricity & V0219 \\
\hline & Piped water & V0213 \\
\hline & Sewage & V0217 \\
\hline & Garbage collection & V0218 \\
\hline \multirow[t]{7}{*}{ Transportation } & Transportation time first job & V9057 \\
\hline & Monthly income first job & V9532 \\
\hline & Weekly work hours first job & V9058 \\
\hline & Hourly wage first job & $\begin{array}{l}(\text { V9532 * } 12) / \text { V } 9058 * 52.2 \\
\text { Hourly wage * transportation time }\end{array}$ \\
\hline & Transportation Monthly Opportunity Cost & ${ }^{*} 20$ days \\
\hline & Transportation Monthly Monetary Cost & $\begin{array}{l}\mathrm{R} \$ 120 \text { if commute time }>1 \mathrm{hr} \\
\text { Opportunity Cost + Monetary }\end{array}$ \\
\hline & Transportation Monthly Cost & Cost \\
\hline \multirow[t]{2}{*}{$\begin{array}{l}\text { Housing + Transportation } \\
\text { Cost Burden }\end{array}$} & (Rent+Transportation)/Income & $\begin{array}{l}\text { (Monthly Rent + Transportation } \\
\text { Cost)/V4614 }\end{array}$ \\
\hline & $(\mathrm{OER}+$ Transportation $) /($ Income+OER $)$ & $\begin{array}{l}\text { (OER + Transportation } \\
\text { Cost }) /(\text { V4614+OER) }\end{array}$ \\
\hline
\end{tabular}

Source: PNAD 2007-2013 
Table 3: Estimated Housing Needs, RMSP 2007-2013³

\begin{tabular}{|c|c|c|c|c|c|c|}
\hline \multicolumn{7}{|l|}{ Official } \\
\hline & 2007 & 2008 & 2009 & 2011 & 2012 & 2013 \\
\hline Deficit & 552,976 & 465,465 & 557,376 & 497,528 & 557,119 & 612,867 \\
\hline Precarious Wall & 39,696 & 19,848 & 23,223 & 29,393 & 43,735 & 31,920 \\
\hline Overcrowding Renter & 132,942 & 119,093 & 152,893 & 99,713 & 113,513 & 152,152 \\
\hline Cohabitating & 167,092 & 133,983 & 168,379 & 154,299 & 119,765 & 142,577 \\
\hline Renter Cost Burden & 273,253 & 235,212 & $\begin{array}{r}275,782 \\
1,013,17\end{array}$ & $\begin{array}{r}248,755 \\
1,016,07\end{array}$ & 322,803 & 336,226 \\
\hline Inadequacy & 953,637 & 956,708 & 0 & 0 & 821,615 & 845,892 \\
\hline Precarious Roof & 2,771 & 7,939 & 11,613 & 7,346 & 0 & 7,449 \\
\hline Lack Services & 426,504 & 425,751 & 405,451 & 346,383 & 259,297 & 278,769 \\
\hline Lack Bathroom & 72,936 & 45,659 & 51,285 & 59,827 & 56,233 & 57,456 \\
\hline Lack Title & 478,205 & 521,017 & 544,812 & 547,916 & 440,486 & 436,250 \\
\hline Overcrowding Owner & $\begin{array}{r}228,948 \\
1,506,61\end{array}$ & $\begin{array}{r}222,310 \\
1,422,17\end{array}$ & $\begin{array}{r}251,603 \\
1,570,54\end{array}$ & $\begin{array}{r}213,091 \\
1,513,59\end{array}$ & $\begin{array}{r}180,147 \\
1,378,73\end{array}$ & $\begin{array}{r}206,419 \\
1,458,75\end{array}$ \\
\hline Deficit + Inadequacy & 3 & 3 & 6 & 8 & 4 & 9 \\
\hline \multicolumn{7}{|l|}{ Proposed } \\
\hline & $\begin{array}{r}\mathbf{2 0 0 7} \\
2,010,64\end{array}$ & $\begin{array}{r}\mathbf{2 0 0 8} \\
2,118,89\end{array}$ & $\begin{array}{r}\mathbf{2 0 0 9} \\
2,138,57\end{array}$ & $\begin{array}{r}\mathbf{2 0 1 1} \\
2,313,39\end{array}$ & $\begin{array}{r}\mathbf{2 0 1 2} \\
2,326,36\end{array}$ & $\begin{array}{r}\mathbf{2 0 1 3} \\
2,607,89\end{array}$ \\
\hline Housing Deficiencies & 9 & 8 & 7 & 9 & 3 & 0 \\
\hline Precarious & 48,930 & 32,751 & 46,451 & 46,187 & 58,314 & 53,201 \\
\hline Lack Services & 691,455 & 877,299 & 672,529 & 517,458 & 483,183 & 519,237 \\
\hline Lack Title & 478,205 & 521,017 & 544,812 & 547,916 & 440,486 & 436,250 \\
\hline Overcrowding & 72,934 & 50,616 & 52,251 & 48,285 & 39,574 & 71,288 \\
\hline Cohabitating & 154,168 & 120,088 & 152,897 & 121,762 & 98,940 & 122,361 \\
\hline Comodo & 12,924 & 13,895 & 17,417 & 32,537 & 20,825 & 20,216 \\
\hline Housing + Transportation & $1,167,78$ & $1,110,58$ & $1,249,29$ & $1,510,42$ & $1,630,74$ & $1,905,63$ \\
\hline \multirow[t]{2}{*}{ Cost Burden } & 5 & 7 & 8 & 2 & 3 & 9 \\
\hline & $1,123,47$ & $1,196,89$ & $1,157,36$ & $1,405,47$ & $1,570,33$ & $1,700,28$ \\
\hline \multirow[t]{2}{*}{ Housing Cost Burden } & 3 & 3 & 1 & 3 & 9 & 1 \\
\hline & $5,760,53$ & $5,994,36$ & $5,905,71$ & $6,395,52$ & $6,697,82$ & $6,729,85$ \\
\hline Number of Households & 6 & 1 & 6 & 0 & 6 & 5 \\
\hline
\end{tabular}

Source: PNAD 2007-2013.

\footnotetext{
${ }^{3}$ The numbers for deficit, inadequacy and deficiencies only count ones units with multiple needs (see Appendix 2 for a breakdown of the number of units with more than 1 deficiency). Contrarily to the approach followed by Fundacao Joao Pinheiro, each categories contains all the units with these characteristics.
} 


\begin{tabular}{|c|c|c|c|c|c|c|}
\hline \multicolumn{7}{|l|}{ Official } \\
\hline & 2007 & 2008 & 2009 & 2011 & 2012 & 2013 \\
\hline Deficit & $9.6 \%$ & $7.8 \%$ & $9.4 \%$ & $7.8 \%$ & $8.3 \%$ & $9.1 \%$ \\
\hline Precarious & $0.7 \%$ & $0.3 \%$ & $0.4 \%$ & $0.5 \%$ & $0.7 \%$ & $0.5 \%$ \\
\hline Overcrowding & $2.3 \%$ & $2.0 \%$ & $2.6 \%$ & $1.6 \%$ & $1.7 \%$ & $2.3 \%$ \\
\hline Cohabitating & $2.9 \%$ & $2.2 \%$ & $2.9 \%$ & $2.4 \%$ & $1.8 \%$ & $2.1 \%$ \\
\hline Renter Cost Burden & $4.7 \%$ & $3.9 \%$ & $4.7 \%$ & $3.9 \%$ & $4.8 \%$ & $5.0 \%$ \\
\hline Inadequacy & $16.6 \%$ & $16.0 \%$ & $17.2 \%$ & $15.9 \%$ & $12.3 \%$ & $12.6 \%$ \\
\hline Precarious Roof & $0.0 \%$ & $0.1 \%$ & $0.2 \%$ & $0.1 \%$ & $0.0 \%$ & $0.1 \%$ \\
\hline Lack Services & $7.4 \%$ & $7.1 \%$ & $6.9 \%$ & $5.4 \%$ & $3.9 \%$ & $4.1 \%$ \\
\hline Lack Bathroom & $1.3 \%$ & $0.8 \%$ & $0.9 \%$ & $0.9 \%$ & $0.8 \%$ & $0.9 \%$ \\
\hline Lack Title & $8.3 \%$ & $8.7 \%$ & $9.2 \%$ & $8.6 \%$ & $6.6 \%$ & $6.5 \%$ \\
\hline Overcrowding Owner & $4.0 \%$ & $3.7 \%$ & $4.3 \%$ & $3.3 \%$ & $2.7 \%$ & $3.1 \%$ \\
\hline Deficit + Inadequacy & $26.2 \%$ & $23.7 \%$ & $26.6 \%$ & $23.7 \%$ & $20.6 \%$ & $21.7 \%$ \\
\hline \multicolumn{7}{|l|}{ Proposed } \\
\hline & 2007 & 2008 & 2009 & 2011 & 2012 & 2013 \\
\hline Housing Deficiencies & $34.9 \%$ & $35.3 \%$ & $36.2 \%$ & $36.2 \%$ & $34.7 \%$ & $38.8 \%$ \\
\hline Precarious & $0.8 \%$ & $0.5 \%$ & $0.8 \%$ & $0.7 \%$ & $0.9 \%$ & $0.8 \%$ \\
\hline Lack Services & $12.0 \%$ & $14.6 \%$ & $11.4 \%$ & $8.1 \%$ & $7.2 \%$ & $7.7 \%$ \\
\hline Lack Title & $8.3 \%$ & $8.7 \%$ & $9.2 \%$ & $8.6 \%$ & $6.6 \%$ & $6.5 \%$ \\
\hline Overcrowding & $1.3 \%$ & $0.8 \%$ & $0.9 \%$ & $0.8 \%$ & $0.6 \%$ & $1.1 \%$ \\
\hline Cohabitating & $2.7 \%$ & $2.0 \%$ & $2.6 \%$ & $1.9 \%$ & $1.5 \%$ & $1.8 \%$ \\
\hline $\begin{array}{l}\text { Comodo } \\
\text { Housing + Transportation Cost }\end{array}$ & $0.2 \%$ & $0.2 \%$ & $0.3 \%$ & $0.5 \%$ & $0.3 \%$ & $0.3 \%$ \\
\hline Burden & $20.3 \%$ & $18.5 \%$ & $21.2 \%$ & $23.6 \%$ & $24.3 \%$ & $28.3 \%$ \\
\hline Housing Cost Burden & $19.5 \%$ & $20.0 \%$ & $19.6 \%$ & $22.0 \%$ & $23.4 \%$ & $25.3 \%$ \\
\hline
\end{tabular}

Source: PNAD 2007-2013. 
Figure 1: Renal rate by income decile, RMSP 2013

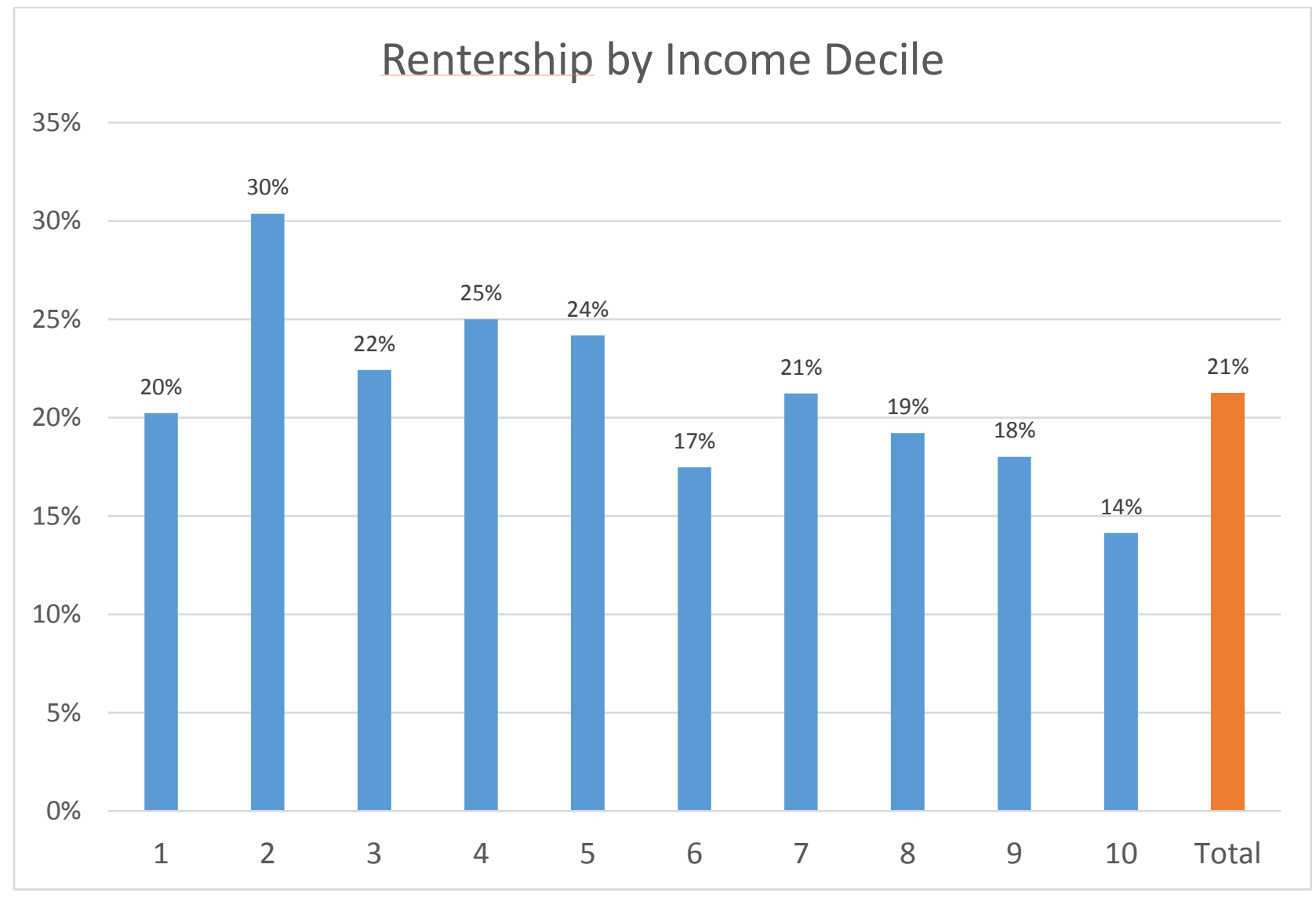

Source: PNAD 2013 
Figure 2: Commute Time Over 1 Hour by Area de Ponderacao

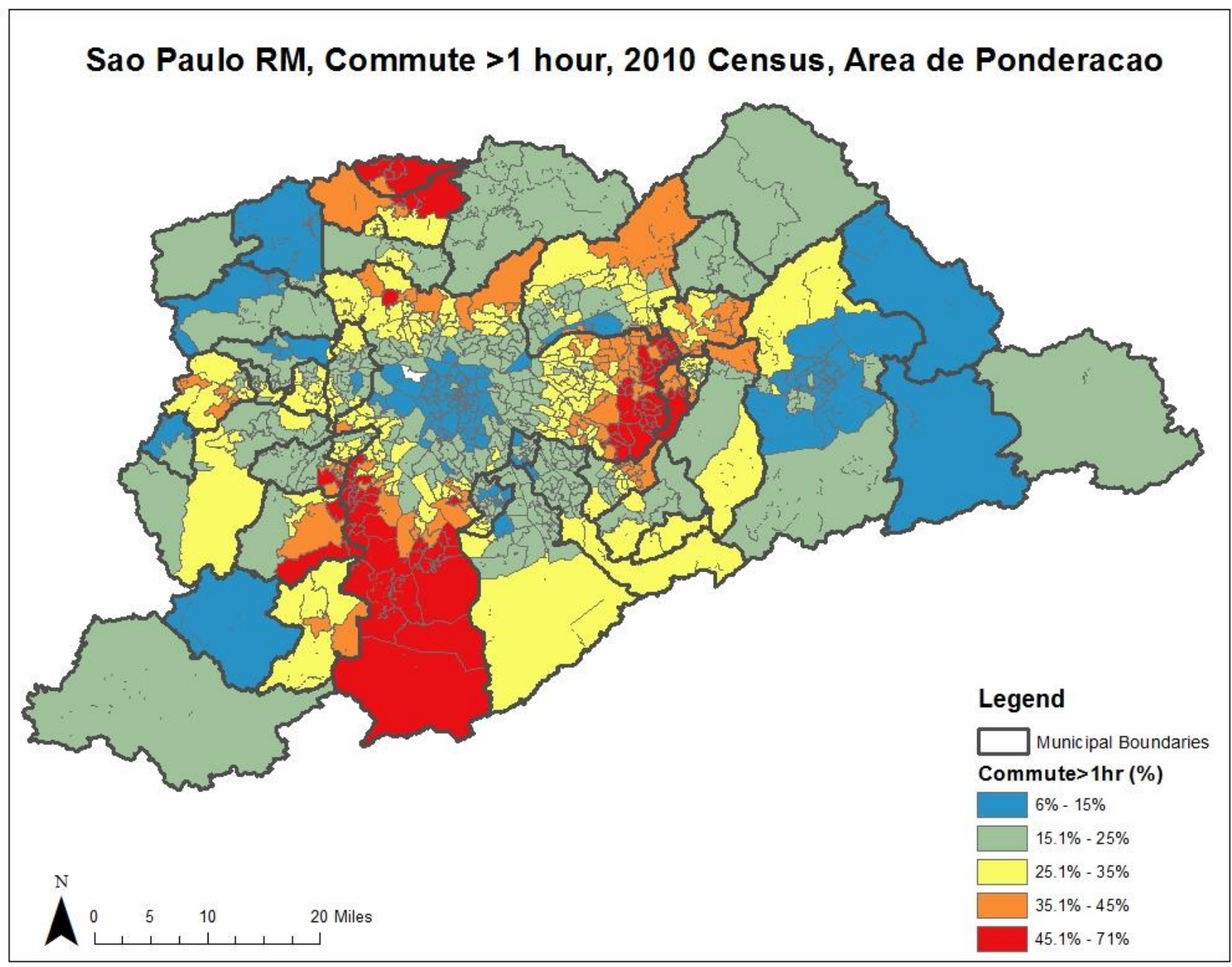

Source: Census, 2010 
Figure 3: Distribution of Formal Employment and Social Vulnerability Indicators

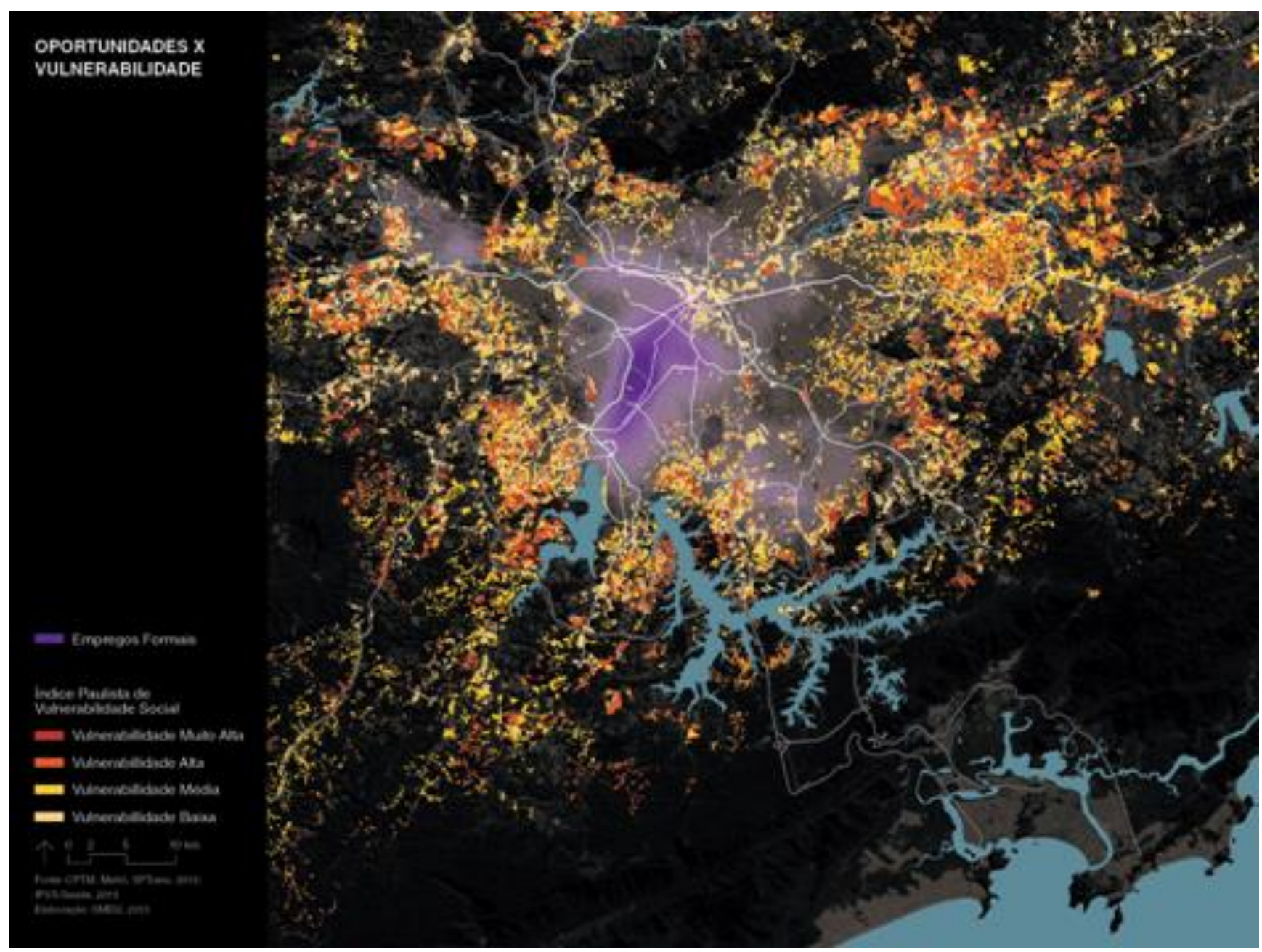

Source: de Mello Franco, 2013 
Appendix 1: Hedonic Model Predicting Rent

\begin{tabular}{|c|c|c|c|c|c|c|}
\hline $\mathrm{DV}=\mathrm{Log}($ Rent $)$ & 2007 & 2008 & 2009 & 2011 & 2012 & 2013 \\
\hline Number of Room & $\begin{array}{c}0.198^{* * *} \\
(0.008)\end{array}$ & $\begin{array}{c}0.214^{* * *} \\
(0.008)\end{array}$ & $\begin{array}{c}0.197^{\star \star *} \\
(0.010)\end{array}$ & $\begin{array}{c}0.205^{\star \star *} \\
(0.008)\end{array}$ & $\begin{array}{c}0.198^{* * *} \\
(0.008)\end{array}$ & $\begin{array}{c}0.230^{* * *} \\
(0.009)\end{array}$ \\
\hline \multicolumn{7}{|c|}{ Dwelling Type (ref.=House) } \\
\hline Apartment & $\begin{array}{c}0.335^{\star * \star} \\
(0.033)\end{array}$ & $\begin{array}{c}0.329^{* * *} \\
(0.031)\end{array}$ & $\begin{array}{c}0.289^{* * *} \\
(0.037)\end{array}$ & $\begin{array}{c}0.502^{\star * *} \\
(0.037)\end{array}$ & $\begin{array}{c}0.575^{\star \star \star} \\
(0.039)\end{array}$ & $\begin{array}{c}0.510^{* * *} \\
(0.039)\end{array}$ \\
\hline Comodo & $\begin{array}{c}0.174 \\
(0.197)\end{array}$ & $\begin{array}{c}-0.422^{* *} \\
(0.203)\end{array}$ & $\begin{array}{c}-0.411^{\star * *} \\
(0.121)\end{array}$ & $\begin{array}{c}-0.129 \\
(0.168)\end{array}$ & $\begin{array}{c}-0.122 \\
(0.141)\end{array}$ & $\begin{array}{c}0.13 \\
(0.080)\end{array}$ \\
\hline Private Bathroom & $\begin{array}{l}0.0499 \\
(0.082)\end{array}$ & $\begin{array}{l}0.0139 \\
(0.239)\end{array}$ & $\begin{array}{c}0.183 \\
(0.127)\end{array}$ & $\begin{array}{l}0.0747 \\
(0.155)\end{array}$ & $\begin{array}{c}0.115 \\
(0.137)\end{array}$ & $\begin{array}{c}0.197 \\
(0.122)\end{array}$ \\
\hline \multicolumn{7}{|c|}{ Wall Material (ref.=Masonry) } \\
\hline Milled Wood or Other & $\begin{array}{l}-0.248 \\
(0.219)\end{array}$ & $\begin{array}{c}0.376^{\star \star \star} \\
(0.139)\end{array}$ & - & $\begin{array}{c}-0.298 \\
(0.249)\end{array}$ & $\begin{array}{c}0.131 \\
(0.102)\end{array}$ & $\begin{array}{l}-0.0486 \\
(0.300)\end{array}$ \\
\hline \multicolumn{7}{|l|}{ Roof Material (ref.=Tile) } \\
\hline Concrete & $\begin{array}{c}-0.119^{* * *} \\
(0.024)\end{array}$ & $\begin{array}{l}-0.0379 \\
(0.023)\end{array}$ & $\begin{array}{c}-0.0897^{* * *} \\
(0.024)\end{array}$ & $\begin{array}{c}-0.0114 \\
(0.026)\end{array}$ & $\begin{array}{c}-0.0210 \\
(0.025)\end{array}$ & $\begin{array}{c}-0.00056 \\
(0.023)\end{array}$ \\
\hline Other & $\begin{array}{l}-0.289^{*} \\
(0.174)\end{array}$ & $\begin{array}{l}-0.143 \\
(0.222)\end{array}$ & $\begin{array}{l}-0.124 \\
(0.091)\end{array}$ & $\begin{array}{c}-0.0292 \\
(0.087)\end{array}$ & $\begin{array}{c}0.00791 \\
(0.060)\end{array}$ & $\begin{array}{l}-0.143 \\
(0.155)\end{array}$ \\
\hline \multicolumn{7}{|l|}{ Sewage (ref.=Sewer) } \\
\hline Sceptic Tank & $\begin{array}{c}-0.149^{\star * *} \\
(0.042)\end{array}$ & $\begin{array}{c}-0.204^{* * *} \\
(0.062)\end{array}$ & $\begin{array}{c}-0.232^{* * *} \\
(0.055)\end{array}$ & $\begin{array}{c}-0.340^{* * *} \\
(0.071)\end{array}$ & $\begin{array}{c}-0.150^{\star *} \\
(0.074)\end{array}$ & $\begin{array}{c}-0.380^{\star * *} \\
(0.082)\end{array}$ \\
\hline Other & $\begin{array}{c}-0.463^{* * *} \\
(0.052)\end{array}$ & $\begin{array}{c}-0.396^{\star * *} \\
(0.062)\end{array}$ & $\begin{array}{c}-0.304^{* * *} \\
(0.045)\end{array}$ & $\begin{array}{c}-0.322^{* * *} \\
(0.069)\end{array}$ & $\begin{array}{l}-0.174^{*} \\
(0.101)\end{array}$ & $\begin{array}{l}-0.208^{* *} \\
(0.086)\end{array}$ \\
\hline \multicolumn{7}{|c|}{ Garbage Collection (ref.=coll. direct) } \\
\hline Other & $\begin{array}{c}-0.134^{* *} \\
(0.056)\end{array}$ & $\begin{array}{c}0.00428 \\
(0.054)\end{array}$ & $\begin{array}{c}-0.199^{* *} \\
(0.096)\end{array}$ & $\begin{array}{c}-0.0119 \\
(0.082)\end{array}$ & $\begin{array}{c}-0.252^{* *} \\
(0.118)\end{array}$ & $\begin{array}{l}-0.140^{*} \\
(0.073)\end{array}$ \\
\hline Commuting Length & $\begin{array}{c}-0.0919^{* * *} \\
(0.023)\end{array}$ & $\begin{array}{c}-0.0579^{* *} \\
(0.023)\end{array}$ & $\begin{array}{c}-0.0934^{* * *} \\
(0.022)\end{array}$ & $\begin{array}{c}-0.0622^{* * *} \\
(0.024)\end{array}$ & $\begin{array}{c}-0.0777^{* * *} \\
(0.022)\end{array}$ & $\begin{array}{c}-0.137^{* * *} \\
(0.022)\end{array}$ \\
\hline Constant & $\begin{array}{c}5.170^{* * *} \\
(0.037)\end{array}$ & $\begin{array}{c}4.883^{* * *} \\
(0.243)\end{array}$ & $\begin{array}{c}4.701^{* * *} \\
(0.159)\end{array}$ & $\begin{array}{c}5.123^{* * *} \\
(0.044)\end{array}$ & $\begin{array}{c}6.050^{* * *} \\
(0.075)\end{array}$ & $\begin{array}{c}5.499^{* * *} \\
(0.078)\end{array}$ \\
\hline Observations & 1,271 & 1,196 & 1,219 & 1,160 & 1,286 & 1,317 \\
\hline R-squared & 0.527 & 0.540 & 0.476 & 0.589 & 0.552 & 0.611 \\
\hline
\end{tabular}

Robust standard errors in parentheses

${ }^{* * *} p<0.01,{ }^{* *} p<0.05,{ }^{*} p<0.1$

Source: PNAD 2007-2013 
Appendix 2: Distribution of the number of housing deficiencies per household

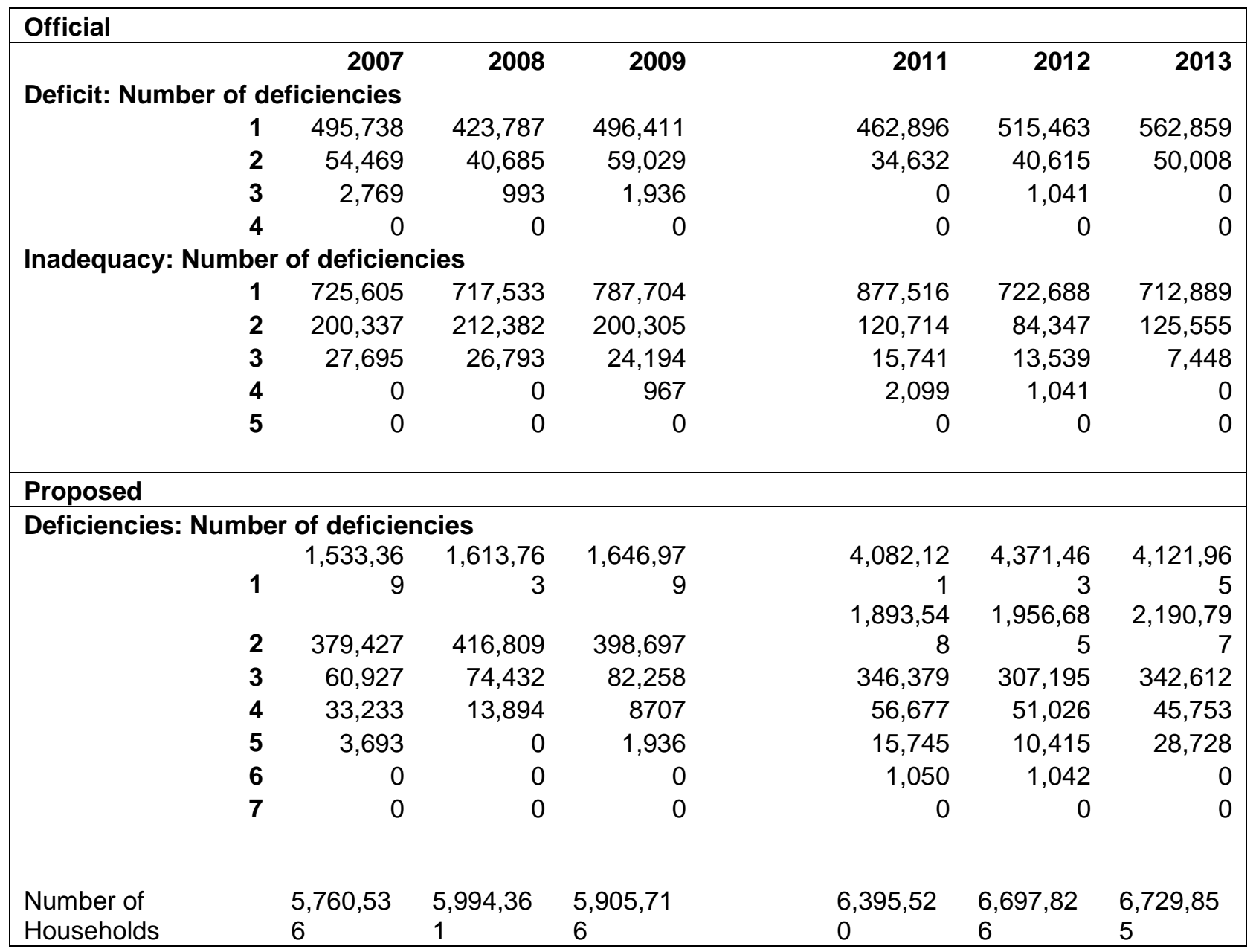

Source: PNAD 2007-2013 